\title{
Induced degradation of crude oil mediated by microbial augmentation and bulking agents
}

\author{
B. Kumari ${ }^{1} \cdot$ S. N. $\operatorname{Singh}^{1} \cdot$ D. P. Singh $^{2}$
}

Received: 28 April 2014/Revised: 11 December 2015/ Accepted: 3 January 2016/Published online: 20 January 2016

(C) Islamic Azad University (IAU) 2016

\begin{abstract}
Different bacterial and fungal strains, isolated from petroleum hydrocarbon-contaminated soil, were tested, in isolation as well as in combination, for their ability to degrade total petroleum hydrocarbon (TPH) in soil samples spiked with crude oil $(2,5$ or $10 \%, w / w)$ for 30 days. The selected combination of bacterial and fungal isolates, i.e., Pseudomonas stutzeri BP10 and Aspergillus niger PS9, exhibited the highest efficiency of TPH degradation $(46.7 \%)$ in soil spiked with $2 \%$ crude oil under control condition. Further, when this combination was applied under natural condition in soil spiked with $2 \%(\mathrm{w} / \mathrm{w})$ crude oil along with inorganic fertilizers (NPK) and different bulking agents such as rice husk, sugarcane, vermicompost or coconut coir, the percent degradation of TPH was found to be maximum $(82.3 \%)$ due to the presence of inorganic fertilizers and rice husk as bulking agent. Further, results showed that the presence of NPK and bulking agents induced the activity of degradative enzymes, such as catalase $\left(0.718 \mathrm{~m} \mathrm{~mol} \mathrm{H}_{2} \mathrm{O}_{2} \mathrm{~g}^{-1}\right)$, laccase $\left(0.77 \mu \mathrm{mol} \mathrm{g}^{-1}\right)$, dehydrogenase $\left(37.5 \mu \mathrm{g} \mathrm{g}^{-1} \mathrm{~h}^{-1}\right)$, catechol 1,2 dioxygenase $\left(276.11 \mu \mathrm{mol} \mathrm{g}^{-1}\right)$ and catechol 2, 3 dioxygenase $\left(15.15 \mu \mathrm{mol} \mathrm{g}^{-1}\right.$ ) as compared to control (without bioaugmentation). It was inferred that the selected combination microbes along with biostimulants could accentuate the crude oil degradation as evident from the biostimulantinduced enhanced activity of degradative enzymes.
\end{abstract}

S. N. Singh

drsn06@gmail.com

1 Environmental Science Division, National Botanical Research Institute, Rana Pratap Marg, Lucknow, UP 226001, India

2 School of Environmental Science, Babasaheb Bhimrao Ambedkar University, Lucknow, India
Keywords Biostimulation - Bioaugmentation - Microbial consortia - Crude oil degradation - Total petroleum hydrocarbon

\section{Introduction}

According to the report of IEO (2014), worldwide consumption of petroleum and other liquid fuels rises to 98 $\mathrm{MMbbl} / \mathrm{d}$ in 2020 and $119 \mathrm{MMbbl} / \mathrm{d}$ in 2040 from 87 $\mathrm{MMbbl} / \mathrm{d}$ in 2010. A huge rise in the consumption of crude petroleum as a major source of energy and a raw material for various petroleum products may result into a large-scale contamination of ecosphere with petroleum hydrocarbons. Sources of oil pollution include accidental discharge of oil spill through bursting of supply pipeline, refining, production, exploration, leakage from tankers and adsorption of combustion emission products onto soil.

Spilling of crude oil, i.e., mixture of toxic alkanes, aromatics, NSO (nitrogen-, sulfur- or oxygen-containing PAH compound) and asphaltenes over on the earth surface is considered as a major environmental threat due to its high toxicity, mutagenicity and carcinogenicity. Several physicochemical cleanup techniques like skimmers, booms, adsorbents, surfactants, chemical oxidants have been applied to remove petroleum hydrocarbons from the contaminated sites, but microbial degradation of petroleum hydrocarbons is a self-driven process with less complexities, high efficiency, eco-friendliness and costeffectiveness. Hence, this technology is gradually gaining ground as compared to conventional techniques (Khashayar and Mahsa 2010). In this process, microbes are employed as natural agents to carry out degradation of crude oil, which leads to its complete mineralization over a period of time. 
In this context, Khashayar and Mahsa (2010) observed that microbes can degrade more than $80 \%$ of individual pure compounds (hexadecane), but they never show the same capability when the same compound is present in diesel and crude oil. The factors, which impact the efficiency of degradation process, include temperature, humidity, presence of surfactants, soil $\mathrm{pH}$, mineral composition, content of organic substances as well as nature of other contaminants (Beškoski et al. 2012). However, soil organic matters (SOM) affect the degradation of petroleum hydrocarbon in soil by hindering the bioavailability of other hydrocarbons to the microbial cell. Liu et al. (2012) reported a reduction in the biodegradation of TPH with increasing level of SOM, whereas Huesemann et al. (2003) suggested that the saturated hydrocarbons need not be transferred from soil particle to the aqueous phase for metabolization by the microorganism, but the degradation of PAHs essentially depends on the desorption from soil matrix. Microbial degradation of petroleum hydrocarbon by native microbes is found to be a slow process, but this process can be further enhanced by bioaugmentation of highly efficient oil-degrading microbes and/or biostimulation process (Agbor et al. 2012). Therefore, successful bioremediation methods depend on both selection of microbes and conducive environment (Boopathy 2000).

Oil spills often result in an imbalance of carbon-nitrogen ratio at the spilled site, because crude oil is mainly composed of $\mathrm{C}$ and $\mathrm{H}$ elements. Nitrogen deficiency in soils soaked with crude oil retards the utilization of carbon sources, resulting in microbial growth (Chromo et al. 2010). Nutrient enrichment of such soil improves both the rate of petroleum hydrocarbon biodegradation and community dynamics of microbial populations. $\mathrm{Xu}$ and $\mathrm{Lu}$ (2010) reported that the bulking agents could increase the degradation rate of crude oil by enhanced $\mathrm{O}_{2}$ diffusion and supply of water and nutrients which are essential for microbial growth.

The present study was carried out at CSIR-NBRI, Lucknow (India), during the period of March-May 2013 to determine the most suitable combination of autochthonous bacterial and fungal strains with high efficiency of crude oil degradation. Subsequently, a microcosmic study was designed to evaluate the role of inorganic fertilizers and selected bulking agents on the microbial efficacy of crude oil degradation.

\section{Materials and methods}

\section{Sample collection and material}

Samples of crude oil and crude oil-contaminated soil were procured from the campus of Barauni Oil Refinery,
Begusarai, Bihar (India), for isolation of bacteria and fungi, while non-contaminated soil was collected from CSIRNBRI Garden, Lucknow (India), for microcosmic study.

\section{Screening and identification of crude oil-degrading microbial strains}

Hundred $\mathrm{ml}$ sterilized minimal salt medium (MSM, composition: $7 \mathrm{~g} \mathrm{~K}_{2} \mathrm{HPO}_{4}, 2 \mathrm{~g}$ mono $\mathrm{KH}_{2} \mathrm{PO}_{4}, 0.5 \mathrm{~g}$ sodium citrate, $1 \mathrm{~g}\left(\mathrm{NH}_{4}\right)_{2} \mathrm{SO}_{4}, \quad 0.1 \mathrm{~g} \quad \mathrm{MgSO}_{4}$ in $1.0 \mathrm{~L}$, $\mathrm{pH}=7.0 \pm 0.2$ ) supplemented with two grams of crude oil-contaminated soil was incubated at $37^{\circ} \mathrm{C}$ and $150 \mathrm{rpm}$ in an orbital shaker to enrich the petroleum hydrocarbondegrading bacterial and fungal strains. After $7 \mathrm{~d}$ of incubation, active inoculum $(1 \mathrm{ml})$ was added to the flasks having fresh sterilized media (MSM) supplemented with the crude oil $(2 \%, \mathrm{w} / \mathrm{v})$. After 3 transfers in similar manner, the active inoculum was used for the isolation of TPH-degrading bacteria and fungi by using serial dilution and spreading over the nutrient agar plates (NA, composition: $10 \mathrm{~g}$ peptic digest of animal tissue, $5 \mathrm{~g} \mathrm{NaCl}, 5 \mathrm{~g}$ beef extract and $15 \mathrm{~g}$ agar in $1 \mathrm{~L}, \mathrm{pH} 7.4 \pm 0.2$ ) and potato dextrose agar plates (PDA, composition: $200 \mathrm{~g}$ potato infusion, $20 \mathrm{~g}$ dextrose and $15 \mathrm{~g}$ agar in $1.0 \mathrm{~L}$ medium with pH $5.6 \pm 0.2$ ), respectively. The colonies were picked up by using standard microbiological techniques on NA and PDA plates to get pure culture of bacteria and fungi, respectively. One petroleum hydrocarbon-degrading bacterial strain (NJ2) was hired from CSIR-NIEST, Jorhat, West Bengal, India.

Isolated 10 bacterial strains along with $\mathrm{NJ} 2$ and 07 fungal strains were incubated on MSM agar supplemented with crude oil as a sole source of carbon. Faster-growing three bacterial and three fungal strains were further tested for degradation ability in MSM broth supplemented with $2 \%(\mathrm{w} / \mathrm{v})$ crude oil and placed on an orbital shaker at $150 \mathrm{rpm}$ and $35^{\circ} \mathrm{C}$ for $10 \mathrm{~d}$. An abiotic control with similar set of condition was also incubated. After $10 \mathrm{~d}$ of incubation, residual amount of total petroleum hydrocarbon (TPH) was extracted from MSM broth using sequential extraction procedure with respective order by hexane, dichloromethane and chloroform to extract the different components of TPH, i.e., alkanes, PAHs, NSO and asphaltene. All extracts were pooled in pre-weighted beaker, and TPH was analyzed by gravimetric method (Mishra et al. 2001).

Based on the finding of this experiment, two bacterial strains and one fungal strain that showed maximum total petroleum hydrocarbon (TPH) degradation were selected for the study of crude oil degradation in soil. These selected bacterial strains were identified using $16 \mathrm{~s}$ rDNA (Kumari et al. 2012). However, fungal strain was identified in NBRI, Lucknow, using morphological and other 
microscopic characteristics as described in fungal manual (Gilman 1990).

\section{Optimization of crude oil concentration in soil for microbial degradation}

Degradation of total petroleum hydrocarbon (TPH) was studied in 10-g sieved $(2 \mathrm{~mm})$ soil taken on the glass petri dishes spiked with different concentrations of crude oil (2, 5 or $10 \%, \mathrm{w} / \mathrm{w}$ ). Bacterial strains, i.e., BP10 and NJ2, were harvested after growing in nutrient broth for $24 \mathrm{~h}$ at $35{ }^{\circ} \mathrm{C}$ in an orbital shaker at $150 \mathrm{rpm}$. Now, bacterial cells were suspended in sterilized distilled water to reach the CFU of strains about $10^{6} \mathrm{CFU} \mathrm{ml}{ }^{-1}$. Inoculum of PS9 was prepared by suspending the biomass of freshly grown PS9 in sterilized water so that inoculum density became approx. $10^{6}$ spores $\mathrm{ml}^{-1}$. Three replicates of each spiked soil were inoculated with each of the selected microbial strains (BP10, NJ2 and PS9) individually as well as in different combinations viz. BP10 + NJ2, BP10 + PS9, NJ2 + PS9, $\mathrm{BP} 10+\mathrm{NJ} 2+\mathrm{PS} 9$ using the same inoculum size. Soils were incubated at room temperature $\left(25 \pm 2{ }^{\circ} \mathrm{C}\right)$, and moisture level was maintained at $60-70 \%$ by using sterilized double-distilled water. Soil was mixed with the help of sterilized sticks on alternate days to maintain aerobic condition.

After 30 days of incubation period, TPH was extracted from soil samples using soxhlet extraction method and the extracts were analyzed by the gravimetric method. Five grams of soil sample was taken in a porous cellulose thimble $(25 \times 70 \mathrm{~mm})$ and placed in a soxhlet extractor. The extractor was consecutively loaded with equal volumes of hexane, dichloromethane, methanol and chloroform $(100 \mathrm{ml}$ each). Extracted solutions were pooled in pre-weighted beakers and evaporated for quantification of different hydrocarbon fractions.

\section{Microcosmic study for crude oil degradation using bulking agents}

Bulking agents are materials of lower bulk density than the soil. When it is added to the soil, it reduces bulk density of soil and increases soil porosity and oxygen diffusion as well as stability of soil aggregates. An experiment was designed to study the effect of bioaugmentation in the presence of biostimulants like inorganic fertilizer (NPK) and four bulking agents: rice husk, sugarcane bagasse, vermicompost and coconut coir with bulk density of 0.31 , $0.84,0.44$ and $0.31 \mathrm{~g} / \mathrm{cc}$. Twenty-four earthen pots (eight sets with three replicas) were selected, and each one was filled with $2 \mathrm{~kg}$ soil (soil was air-dried, sieved through 2-mm sieve) and $40 \mathrm{~g}$ of crude oil. These pots were treated with different amendments as described in Table 1. Pot
(SC1) without bioaugmentation or addition of biostimulants (inorganic fertilizer or bulking agents) was taken as control as it corresponded with natural conditions (both biotic and abiotic) for degradation of crude oil in soil. Microbial consortium and inorganic fertilizer were added, separately, in SC2 and SC3 pots, respectively, but a combination of these two in SC4 was carried out to see the individual as well as cumulative effects on the degradation of crude oil. Besides, bulking agents, i.e., rice husk, sugarcane bagasse, vermicompost and coconut coir, were added separately in pots SC5, SC6, SC7 and SC8, respectively. All the pots including control set were kept in similar natural condition. The moisture content of all the pots was maintained at $60-70 \%$ with distilled water throughout experimentation period. Soil samples from each pot were collected at interval of 10 days and preserved at $4{ }^{\circ} \mathrm{C}$ till all the parameters such as residual petroleum hydrocarbons, microbial biomass, soil $\mathrm{pH}$ and enzymes assays were analyzed.

\section{Analysis of TPH and their fractions}

TPH of the soil samples was extracted and analyzed gravimetrically as described in Sect. 2.3. To analyze different fractions of residual TPH, its dissolved fraction was extracted in $n$-pentane and separated by syringe filter and finally analyzed through gravimetric method. Remaining undissolved fraction was termed as asphaltenes. The dissolved fraction was loaded onto silica gel column. Other fractions of petroleum hydrocarbons, such as alkane, aromatic and NSO, were eluted from dissolved fraction by using $100 \mathrm{ml}$ of different organic solvents, i.e., hexane, benzene and methanol + chloroform, respectively. These fractions were analyzed gravimetrically.

Aliphatic and aromatic compounds were further analyzed by GC-FID (Agilent 7890A). Injection and detector temperatures were maintained at $280{ }^{\circ} \mathrm{C}$. The initial oven temperature was kept at $50{ }^{\circ} \mathrm{C}$ for $3 \mathrm{~min}$ and then increased to $100{ }^{\circ} \mathrm{C}$ with increment rate of $5{ }^{\circ} \mathrm{C}$ per min. After holding the $100{ }^{\circ} \mathrm{C}$ temperature for $2 \mathrm{~min}$, the temperature was again enhanced at a rate of $5{ }^{\circ} \mathrm{C} \mathrm{min}{ }^{-1}$ till it attained $250{ }^{\circ} \mathrm{C}$. Again after holding the temperature for $2 \mathrm{~min}$, the temperature was increased to $300{ }^{\circ} \mathrm{C}$ with same rate of increment. The injection volume taken for analysis was $5 \mu \mathrm{l}$.

\section{Microbial growth analysis}

Growth of soil bacteria and fungi was measured in terms of CFU $\mathrm{g}^{-1}$ of soil by serial dilution. The survival of bioaugmented bacterial and fungal strains (BP10 and PS9) was also monitored. Bacterial strain (BP10) was tagged with vancomycin at $250 \mathrm{mg} \mathrm{L}^{-1}$ (Kumari et al. 2013) so 
Table 1 Amendments of different treatments

\begin{tabular}{ll}
\hline Treatment code & Amendments \\
\hline SC1 & Soil + crude oil \\
SC2 & Soil + crude oil + microbial consortium \\
SC3 & Soil + crude oil + NPK \\
SC4 & Soil + crude oil + microbial consortium + NPK \\
SC5 & Soil + crude oil + microbial consortium + NPK + Rice husk \\
SC6 & Soil + crude oil + microbial consortium + NPK + Sugarcane bagasse \\
SC7 & Soil + crude oil + microbial consortium + NPK + vermicompost \\
SC8 & Soil + crude oil + microbial consortium + NPK + coconut coir \\
\hline
\end{tabular}

Where NPK = inorganic source of nitrogen, phosphorous and potassium $\left(1.2 \mathrm{~g}\left(\mathrm{NH}_{4}\right)_{2} \mathrm{SO}_{4}\right.$ and $3.67 \mathrm{~g}$ $\mathrm{K}_{2} \mathrm{HPO}_{4}$

that it could be easily distinguished from other soil bacteria on nutrient agar (NA) plate supplemented with vancomycin. CFU of total soil bacteria and bioaugmented bacterium (BP10) was determined by counting the colonies developed after $24-48 \mathrm{~h}$ on NA plates supplemented with or without vancomycin $\left(250 \mathrm{mg}^{-1}\right)$. Total number of fungal colonies including bioaugmented fungal strain (PS9) was counted on PDA plate after 7 days of incubation at $30{ }^{\circ} \mathrm{C}$.

\section{Enzymes assay}

Catalase activity Enzyme was extracted in $2 \mathrm{ml}$ extraction buffer (containing $100 \mathrm{mM}$ k phosphate buffer, $\mathrm{pH} 7.0$ and $1 \mathrm{mM}$ EDTA) from $0.25 \mathrm{~g}$ soil with pinch of polyvinyl pyrrolidone. Thereafter, samples were centrifuged at $20,000 \times g$ for $15 \mathrm{~min}$ at $4{ }^{\circ} \mathrm{C}$. The reaction mixture consisted of $1.2 \mathrm{ml}$ phosphate buffer, $0.2 \mathrm{ml}$ hydrogen peroxide $(30 \mathrm{mM})$ and $0.1 \mathrm{ml}$ of enzyme extract. Catalase activity was assayed by recording a decrease in absorbance at $240 \mathrm{~nm}$ occurring due to disappearance of peroxide (Beers and Sizer 1952).

Laccase activity Five $\mathrm{ml}$ of potassium phosphate buffer (pH $6.5,100 \mathrm{mM}$ ) was added to $5 \mathrm{~g}$ soil samples and then centrifuged at $14,000 \times g$ for $10 \mathrm{~min}$. The specific activity of laccase was assayed spectrophotometrically (PerkinElmer Lambda UV-Vis spectrophotometer) by monitoring an increase in absorbance at $530 \mathrm{~nm}\left(\varepsilon=65 \mathrm{mM}^{-1}\right.$ $\mathrm{cm}^{-1}$ ) due to oxidation of syringaldazine. Three milliliters of assay mixture contained $500 \mu \mathrm{l}$ enzyme extract, $2.2 \mathrm{ml}$ phosphate buffer $(\mathrm{pH}$ 6.5) and $300 \mu \mathrm{l}$ of $0.216 \mathrm{mM}$ syringaldazine in absolute methanol.

Dehydrogenase activity Two $\mathrm{ml}$ of Tris buffer $(0.1 \mathrm{M}$, $\mathrm{pH} 7.4$ ) and $2 \mathrm{ml}$ of $1 \%$ triphenyl tetrazolium chloride (prepared in $0.1 \mathrm{M}$ Tris buffer $\mathrm{pH}$ 7.4) solution were added to $2 \mathrm{~g}$ of soil sample and kept for 24-h incubation in an orbital shaker at $180 \mathrm{rpm}$. The product of hydrolytic reaction, i.e., triphenyl formazan, was extracted in $4 \mathrm{ml}$ of methanol by centrifugation at $4{ }^{\circ} \mathrm{C}$ and $3000 \times g$ for $10 \mathrm{~min}$. Formation of formazan was determined by measuring the absorbance at $485 \mathrm{~nm}$ as described by Stevenson (1956).

Catechol dioxygenases Soil protein was extracted by following the method of Rahman et al. (2002). One gram of soil was suspended in $10 \mathrm{ml}$ of distilled water and mixed vigorously on vortex. After settling the soil particles, $1 \mathrm{ml}$ of supernatant was centrifuged at $13,000 \times \mathrm{g}$ for $10 \mathrm{~min}$. Then, the pellet was redissolved in $1 \mathrm{~N} \mathrm{NaOH}(1 \mathrm{ml})$. It was kept for $3 \mathrm{~min}$ in water bath for cell lysis at boiling temperature. After cooling at room temperature $\left(25^{\circ} \mathrm{C}\right)$, $1 \mathrm{ml}$ of $1 \mathrm{M}$ H3PO4 was added.

Catechol 1, 2 dioxygenase (C12O, EC 1.13.11.1) was assayed by using the method of Hegeman (1966) using the colorimetric procedures to detect the product $\mathrm{cis}$, cis $\left.\varepsilon=25,600 \mathrm{l} \mathrm{mol}^{-1} \mathrm{~cm}^{-1}\right)$. The reaction mixture contained $8.7 \mu \mathrm{M}$ sodium phosphate buffer $(\mathrm{pH}=7.0), 1 \mu \mathrm{mol}$ EDTA, $0.1 \mu \mathrm{M}$ catechol and soil protein extract in a final volume of $1 \mathrm{ml}$. An increase in absorbance $\left(\mathrm{A}_{260}\right)$ occurring due to accumulation of cis, cis muconic acid was measured at $260 \mathrm{~nm}$. Amount of enzyme catalyzing the oxidation of $1 \mathrm{nmol}$ of substrate per min represents one unit of enzyme activity.

Catechol 2, 3 dioxygenase (C23O, EC 1.13.11.2) occurs with concomitant formation of 2-hydroxymuconic semialdehyde $(\mathrm{pH}=7.5)$ exhibiting increase in absorbance at $375 \mathrm{~nm}\left(\varepsilon=33,400 \mathrm{~mol}^{-1} \mathrm{~cm}^{-1}\right)$. Reaction mixture of $1 \mathrm{ml}$ contained $48 \mu \mathrm{M}$ sodium phosphate buffer $(\mathrm{pH}=7.5), 0.1 \mu \mathrm{M}$ catechol and soil protein extract. The reaction mixture was heated for $10 \mathrm{~min}$ at $60{ }^{\circ} \mathrm{C}$ before analysis of enzyme activity (Klecka and Gibson 1981).

\section{pH analysis}

$\mathrm{pH}$ of the soil (soil/water ratio; 1:5 w/v) was measured using a $\mathrm{pH}$ meter (Orion EA940) already calibrated by using standard buffer solutions of $\mathrm{pH}=7.0,4.0$ and 10.01. muconate $\quad\left(\mathrm{pH}=7.0, \quad \lambda_{\max }=260 \mathrm{~nm}\right.$; 


\section{Statistical analysis}

All the data were collected in triplicates and represented with the mean value in graph and their standard deviation (as error bar in figure). One-way analysis of variance (ANOVA) and post hoc test, i.e., least significant difference (LSD), were calculated by using MS Excel, specially, to determine the significance differences in the degradation of total petroleum hydrocarbon (TPH) due to augmentation of different microbial strains either in isolation or combination and treatment of different biostimulants at $p \leq 0.05$.

\section{Results and discussion}

\section{Screening and identification of isolated bacterial and fungal strains}

Among eleven bacterial strains and seven fungal strains isolated from the crude oil of Barauni oil refinery, Barauni, Bihar (India), three bacterial strains, i.e., BP10, NJ2 and P2, and three fungal strains, namely PS6, PS8 and PS9, were selected for the present study based on their faster growth on MSM agar plates supplemented with $2 \%$ crude oil as sole carbon source. When these strains were incubated in MSM broth for $10 \mathrm{~d}$ at $150 \mathrm{rpm}$ and $35^{\circ} \mathrm{C}$, the fungal strain PS9 showed the highest degradation of $30.8 \%$ of TPH in the crude oil, followed by BP10 (27.1\%), NJ2 (20.6\%), PS8 (19.3\%), PS6 (15.6\%) and P2 (12.3\%) in a decreasing order (Fig. 1a). Hence, three strains (two bacterial strains, i.e., BP10 and NJ2 and one fungal strain, i.e., PS9) were selected for further study.

Based on the 16S rDNA technique, bacterial strains, i.e., BP10 and NJ2, were identified as Psuedomonas stutzeri and Rhodococcus pyridinivorans, respectively, while PS9 was identified as Aspergillus niger based on morphological and microscopic characteristics.

\section{Screening of microbial combination and optimization of crude oil concentration}

Three microbial strains, i.e., BP10, NJ2 and PS9 showing relatively higher rates of petroleum hydrocarbon degradation were selected for further study either individually or in different combinations (BP10 + NJ2, BP10 + PS9, $\mathrm{NJ} 2+$ PS9 and BP10 + NJ2 + PS9). The soil spiked with 2,5 or $10 \%$ of crude oil was inoculated with selected microbial combinations and then incubated for 30 days under in vitro conditions. The combination of two strains BP10 + PS9 showed the highest rate of hydrocarbon degradation (i.e., 46.7, 35.5 and $22.9 \%$ ) in the soil spiked with 2,5 and $10 \%(\mathrm{w} / \mathrm{w})$ of crude oil, respectively (Fig. 1b). Degradation rate of TPH reduced with increasing the concentration of crude oil in soil in all treatments. In case of either 2 or $10 \%$, LSD analysis showed that there is no significant difference between the degradation of TPH by the microbial combination of $\mathrm{BP} 10+\mathrm{PS} 9$ and $\mathrm{BP} 10+\mathrm{PS} 9+\mathrm{NJ} 2$ at the $p<0.05$, but mean value was always found higher in BP10 + PS9. This clearly indicated that a combination of these two microbes (BP10 + PS9) exhibited better performance at $2 \%$ concentration of crude oil as compared to other microbial combinations at the corresponding concentrations. Wu et al. (2013) have also reported that no single microbial species had the ability to metabolize all classes of petroleum hydrocarbons. After 6 days of incubation, Saccharomyces sp. alone could degrade $39.5 \%$ of crude oil ( $3 \%$ ), while only in 4 days, $41.8 \%$ of crude oil was degraded in the presence of the combination of Actinomyces sp. and Sachharomyces sp. (Shahaby 2014).

F values were calculated as 14.78 and 121.04 at the level of $p<0.05$ among different microbial combinations and concentration of crude oil, respectively. The results indicated that the concentration of crude oil as well as type of microbial communities in soil played significant role in the degradation of crude oil. Binazadeh et al. (2009) also observed a decreasing pattern of alkane degradation, i.e., 51, 37, 20 and $16 \%$ by Rhodococcus Moj-3449 with increasing concentration of crude oil 60, 150, 200 and $250 \mathrm{mg} \mathrm{L}^{-1}$, respectively. Similarly, in the present study, Rhodococcus sp. NJ2 showed decreasing pattern of TPH degradation, i.e., $36.3,32.1$ and $16.8 \%$ with increasing concentration of crude oil $2,5,10 \%$ in soil.

\section{Role of inorganic nutrients and bulking agents on TPH degradation}

Role of different bulking agents, i.e., rice husk, sugarcane bagasse, vermicompost and coconut coir, and inorganic NPK in boosting the degradation of crude oil was ascertained by measuring the extent of TPH degradation in the soil containing $2 \%$ crude oil, selected microbial consortium (BP10 + PS9) and biostimulants. After $30 \mathrm{~d}$ of incubation period, the highest degradation of TPH was found in SC5 $(82.3 \%)$, followed by SC7 (76.3\%), SC8 (73.4), SC6 (76.2\%), SC4 (65.7\%), SC2 (55.5\%), SC3 $(42.3 \%)$ and SC1 $(28.4 \%)$ in a decreasing order (Fig. 2a). A comparison of results on crude oil degradation in bioaugmented soil with and without biostimulants showed that microbial consortium boosted the degradation of crude oil by $27.1 \%$, whereas addition of NPK + microbial consortium enhanced the degradation process by $37.3 \%$. It is quite possible that addition of inorganic NPK helps in improving the microbial biomass. It has been earlier suggested that a proper $\mathrm{C} / \mathrm{N}$ balance is necessary for faster biodegradation of petroleum contaminants (Jin and 
Fig. 1 Degradation of crude oil ( $2 \%)$ by bacterial and fungal strains after $10 \mathrm{~d}$ of incubation (a) and degradation of TPH (\%) in the presence of different concentrations of crude oil and microbial combination

(b) (same alphabetic letter present on SD bar shows there is no significant difference between them at $p<0.05$ level by least significant difference (LSD) analysis)
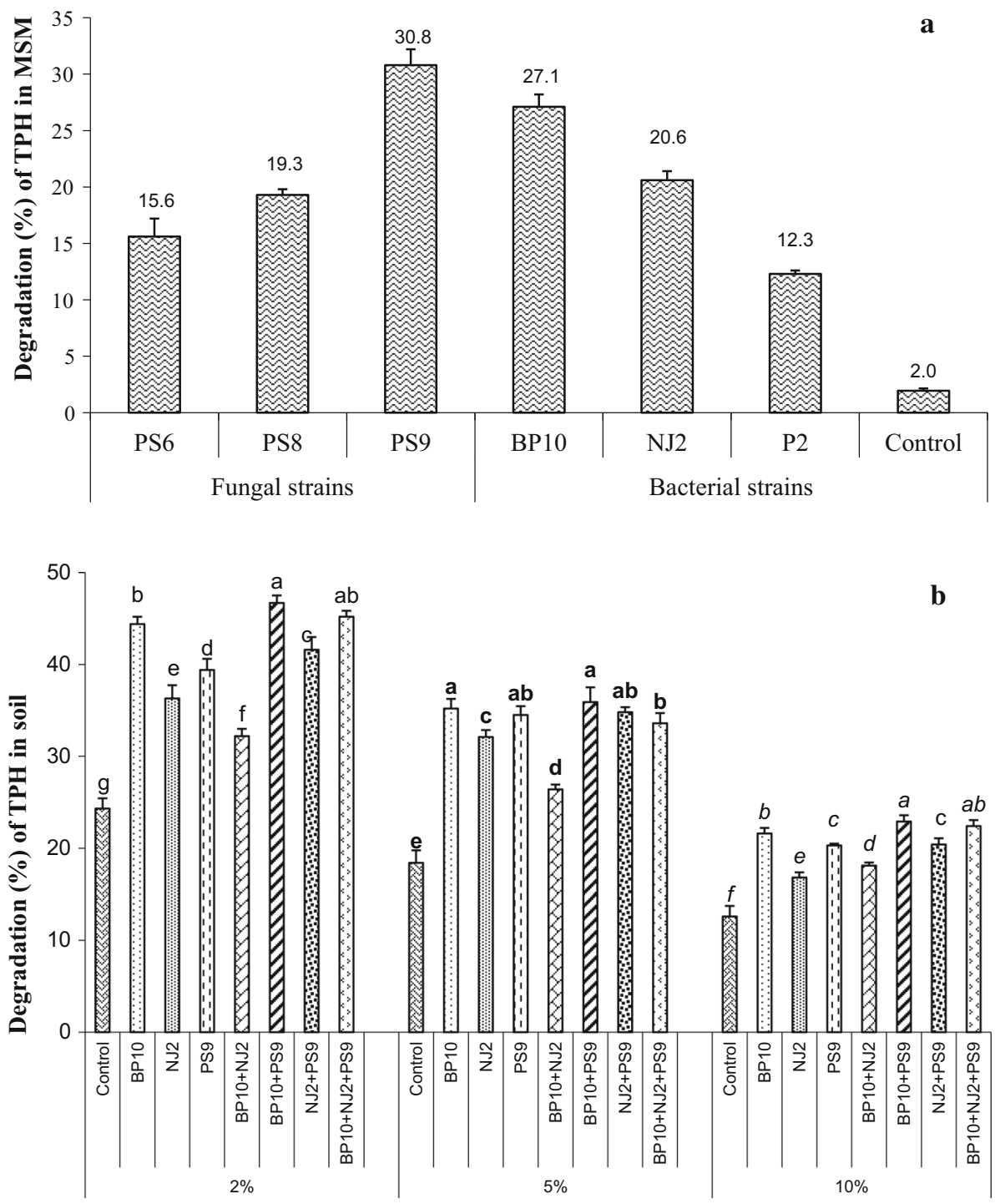

Treatments

Fallgren 2007). Further, results obtained with bulking agents, i.e., rice husk, sugarcane bagasse, vermicompost and coconut coir, showed an enhanced rate of TPH degradation $(53.9,42.8,47.9$ and $45 \%$, respectively) over the control.

Various workers have supported the idea of using consortium instead of monoculture to achieve higher biodegradation efficiency (Kadali et al. 2012; Shahaby 2014). The co-metabolism of individual members of consortium has been found to have complementary effects on the growth and survival of individual members of the consortium (Sampath et al. 2012), which directly or indirectly contributes to stimulated rate of biodegradation. Das et al. (2014) also observed $90 \%$ of crude oil degradation with a consortium of Bacillus sp. and Aspergillus sp. within 22 h. Similarly, Amenaghawon et al. (2014) used a similar combination of Aspergillus and Pseudomonas to treat petroleum hydrocarbon-polluted water and recorded $93.6 \%$ of THC degradation supplemented with bioaugmentation and nutrient. Mortazavi et al. (2013) reported an enhancement in the biodegradation of crude oil by $76 \%$ in intertidal sandy sediments in Gulf of Mexico depending upon the amendment of microbial communities.

It has been earlier reported that bulking materials provide nutrients, moisture and physical support to the growing microbial population in addition to the required aeration which prolongs the shelf life of microbes (Hamzah et al. 2012). Xu and Lu (2010) reported that the presence of bioaugmented bacterial consortia with peanut hull powder as bulking agent enhanced the TPH removal up to $61 \%$ over that of native bacteria after 12 weeks of incubation. The present results showed that the rice husk was more 
Fig. 2 Degradation of TPH (\%) (a) and degradation of different fractions of TPH by different treatments after $30 \mathrm{~d}$ of treatment (b) (same alphabetic letter present on SD bar shows there is no significant difference between them at $p<0.05$ level by least significant difference (LSD) analysis)
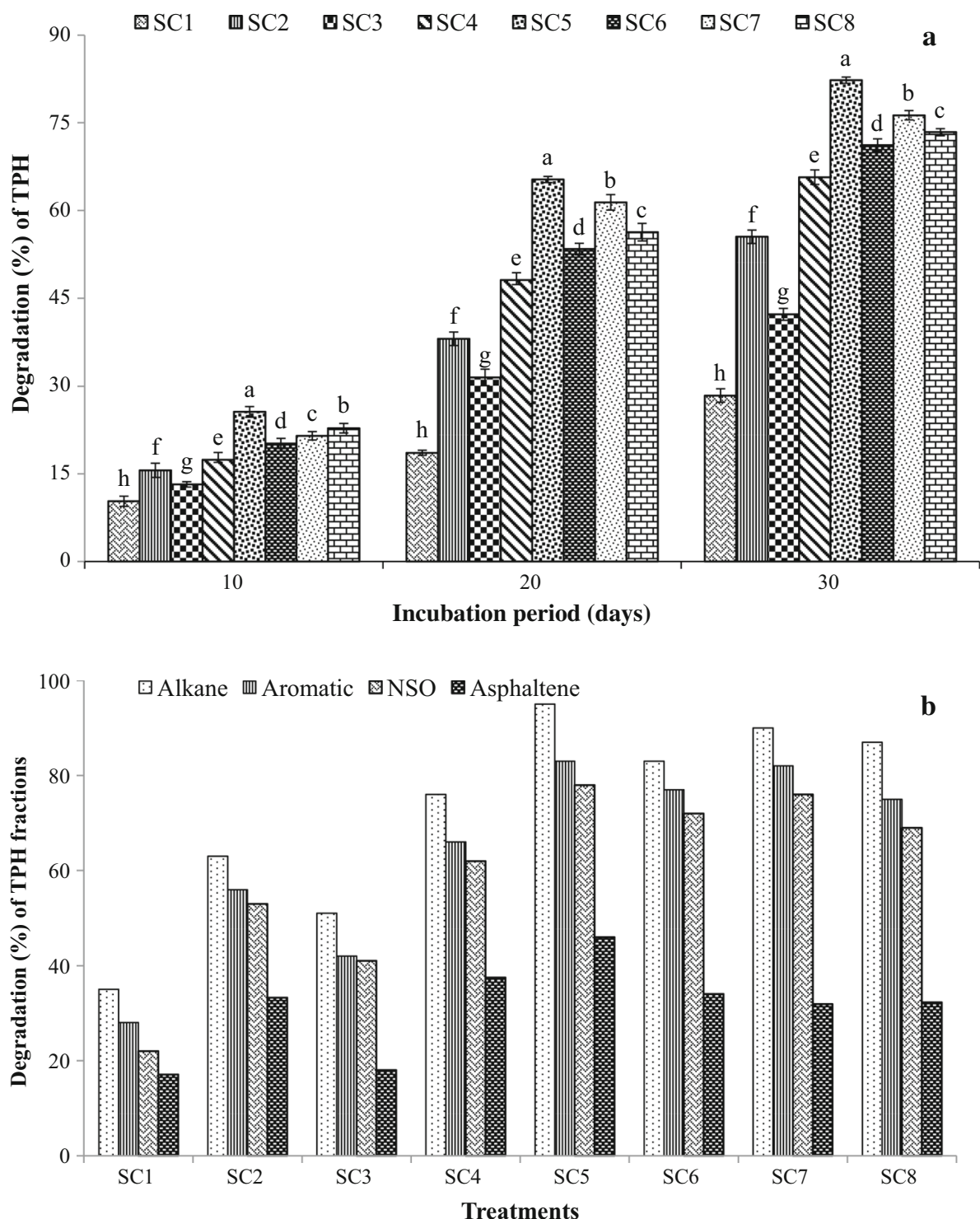

supportive to microbial degradation of TPH than other bulking agents used.

\section{Degradation of aliphatics}

Among different fractions of TPH in the crude oil, the degradation of aliphatic fraction was the highest after 30 days of incubation (Fig. 2b). Bioaugmented microbial consortium along with native microbes could degrade the highest amount of alkane, i.e., $95 \%$ in the presence of rice husk +NPK (SC5), followed by $90 \%$ in SC7, $87 \%$ in $\mathrm{SC} 8,83 \%$ in SC6, $76 \%$ in SC4 and $63 \%$ in SC2, whereas native microbes could degrade only $35 \%$ in SC1 and $51 \%$ in SC3 along with NPK.

As evident from GC chromatogram, the results revealed that high molecular weight aliphatic compounds (C33-C38) were completely degraded in the case of SC6 (Fig. 3), whereas for the same carbon range of aliphatic compounds, the lowest degradation of compounds was recorded in the control set SC1. A comparison of results for all the treatments with bulking agents, i.e., SC5, SC6, SC7 and SC8, showed reduced levels of degradation for high molecular weight alkanes than that in $\mathrm{SC} 1, \mathrm{SC} 2, \mathrm{SC} 3$ and SC4 treatment sets. However, in case of SC5, all the aliphatic compounds in the range of $\mathrm{C} 14-\mathrm{C} 18$ were completely degraded.

Interestingly, residual level of two alkanes with $\mathrm{C} 24$ and C36 was in higher concentrations in SC2, SC3, SC4, SC7 and SC8 treatments after $30 \mathrm{~d}$ of incubation period. Similarly, $\mathrm{Xu}$ and $\mathrm{Lu}$ (2010) also found higher accumulation of residual alkane above $\mathrm{C} 29$ at the end of incubation period in the presence of peanut hull powder with/without immobilized microbial cells. 


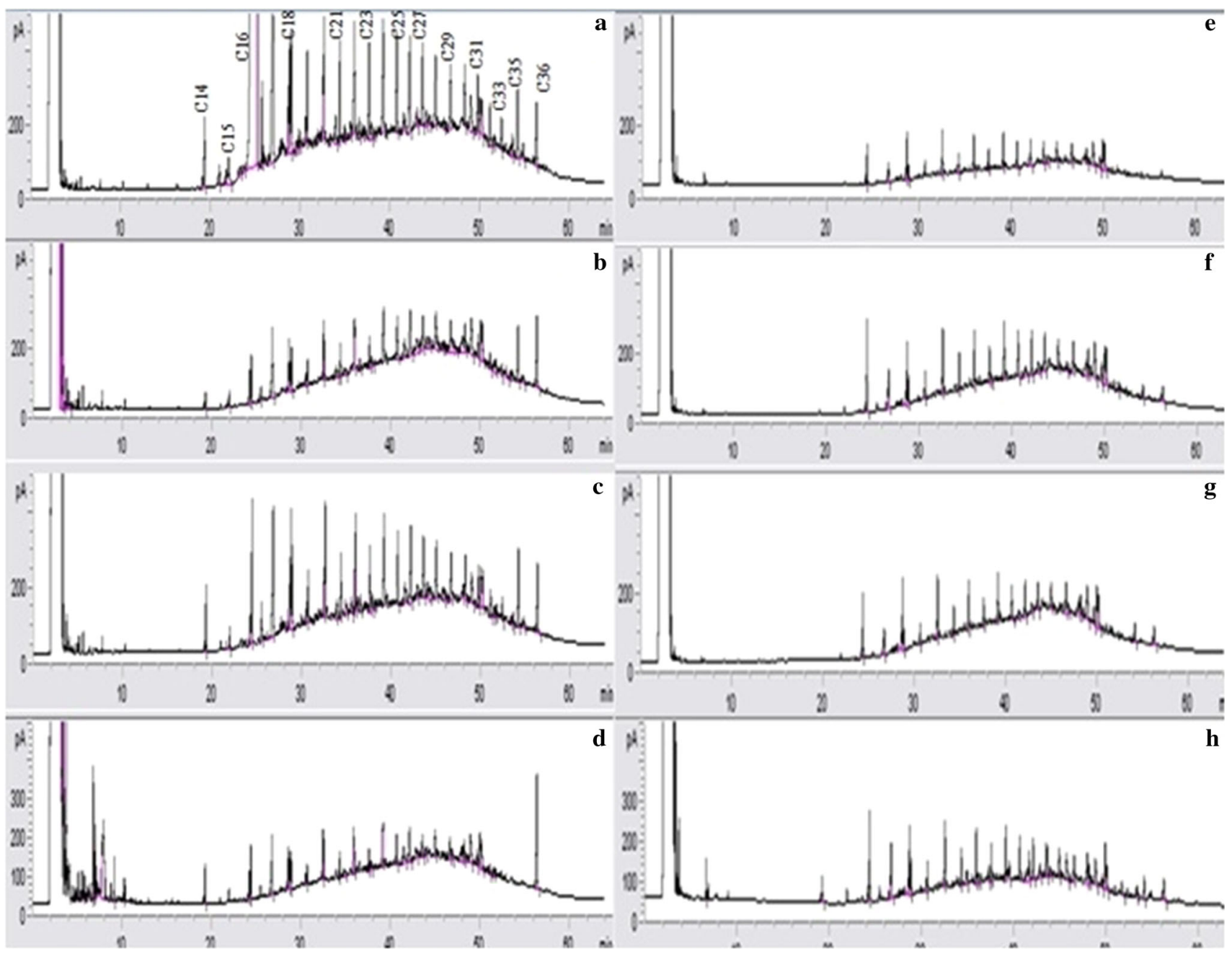

Fig. 3 GC chromatography for residual aliphatic compounds in SC1 (a), SC2 (b), SC3 (c), SC4 (d), SC5 (e), SC6 (f), SC7 (g) and SC8 (h)

Perhaps, due to less hydrophobicity and highly volatile nature, the rate of LMW alkane degradation was faster than HMW alkanes (Kumari et al. 2012). On the contrary, faster degradation of aromatic hydrocarbons in crude oil by Bacillus strain than aliphatic components of crude oil was reported by Rizi et al. (2012).

\section{Degradation of aromatics}

Results indicated that a maximum level of $88 \%$ of aromatic compounds was degraded in SC5 treatment, followed by SC7 (82\%), SC6 (77\%), SC8 (75\%), SC4 (66\%), SC2 (56 \%), SC3 (42\%) and SC1 (28\%) in the decreasing order. A comparison of results in SC2 set (without NPK) and SC4 (with NPK) obtained under bioaugmented (BP10 + PS9) condition showed enhanced degradation of aromatic compounds by 28 and $38 \%$ as compared to SC1 (control set). Among all the bulking agents used, rice husks induced stimulated degradation (17\%) of aromatic compounds (SC5) as compared to SC4 (without bulking agent). When the results on effect of bulking agents was compared, the GC chromatogram of residual amount of aromatic compounds in case of only SC5 showed disappearance of almost all the peaks (except one) due to the presence of rice husk (Fig. 4). This treatment also supported the fastest degradation of high molecular weight PAHs. Among the identified peaks based on the retention time of 16 PAH mix standard, the dibenzo $(\mathrm{a}, \mathrm{h})$ anthracene (a 5-ring PAH) was degraded by about $80-85 \%$ in SC5 containing rice husk as compared to $25-30 \%$ in case of other bulking agents.

\section{Degradation of NSO and asphaltene}

The effect of bulking agents, microbial consortium and biostimulant like NPK on degradation of NSO compounds is evident from the results shown in Fig. 2b. Degradation of NSO compound, analyzed by the gravimetric method, was 
found to be $78 \%$ in SC5, $76 \%$ in SC7, $72 \%$ in SC6, $69 \%$ in $\mathrm{SC} 8,62 \%$ in SC4, $53 \%$ in SC2 and $41 \%$ in SC3, and the lowest $(22 \%)$ was recorded in SC1. Results showed that inoculation of bioaugmented microbes with and without NPK (SC4 and SC2, respectively) contributed to 40 and $31 \%$ increase in the degradation of NSO over the treatment with NPK alone (SC2). Further, addition of bulking agents, like rice husk, vermicompost, coconut coir and sugarcane, could boost up NSO degradation by 16, 14, 10 and $7 \%$, respectively, over the treatment without bulking agents (SC4).

Asphaltenes are highly recalcitrant compounds, and hence, they cannot be easily degraded by microbes. In our experiment, asphaltene was found slowly degraded as compared to other fractions of TPH. Native microbes could degrade only $17 \%$ of asphaltene which could be further enhanced by $18,32,33,34,38$ and $46 \%$ in the case of different treatments, i.e., SC3, SC7/SC8, SC2, SC6, SC4 and SC5, respectively, after 30 days of incubation (Fig. 2b). It clearly indicated that the selected microbial combination (BP10 + PS9) along with NPK and rice husk as bulking agents could further boost up the degradation of petroleum hydrocarbons.

Lavania et al. (2012) specially studied the degradation of asphaltene of heavy oil in the presence of Garciaella petrolearia TERIG02 and molasses and observed that due to the degradation of asphaltene, viscosity of crude oil reduced up to $42 \%$. Li et al. (2004) suggested that sufficient oxygen supply could considerably enhance the biodegradation of hydrocarbons due to an enhanced metabolic activity of degrading microbes. Air dispersion, consolidation and oxygen uptake are found to be influenced by the presence of bulking agents as observed by Trémier and Telia (2009) during a sludge composting.

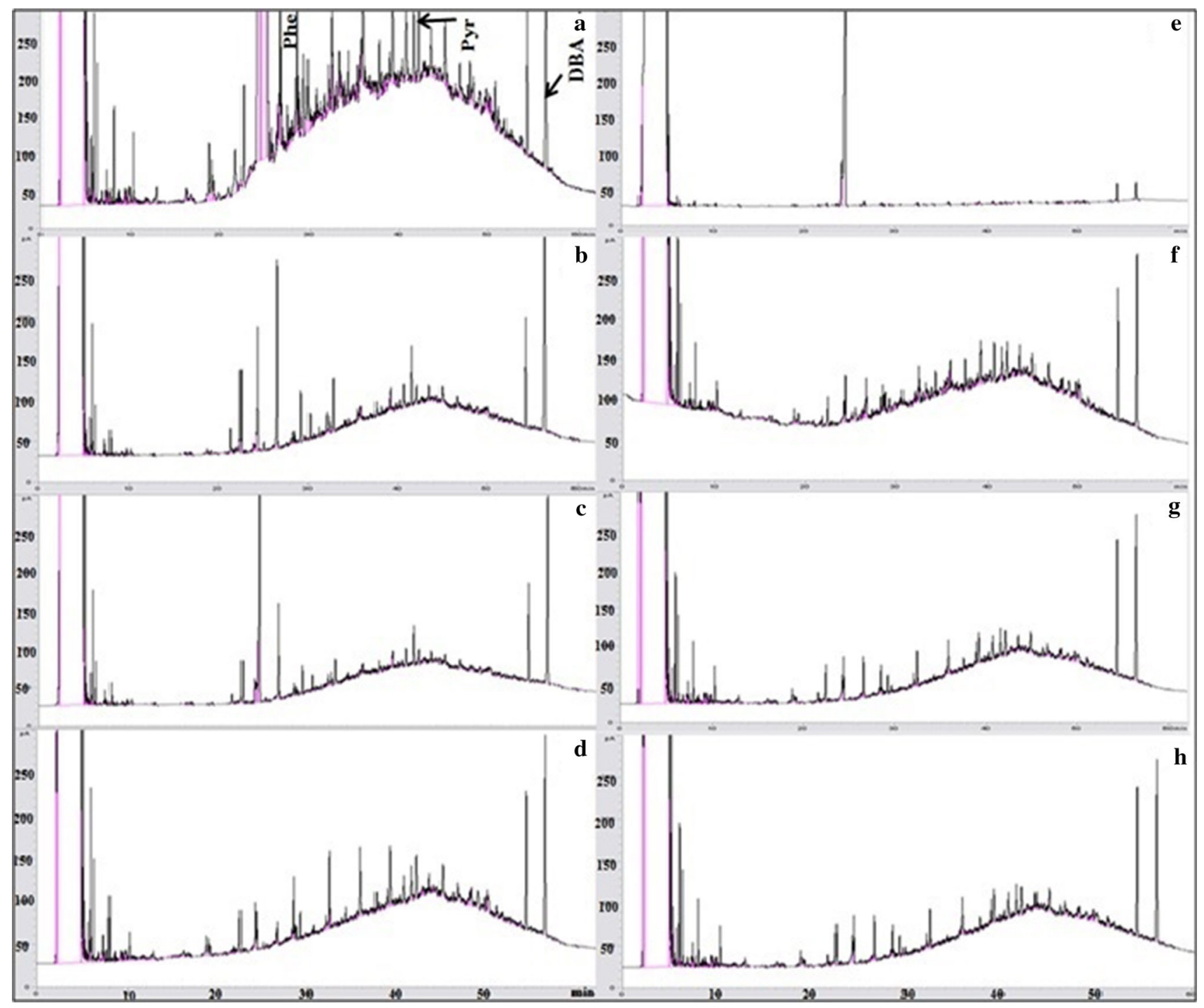

Fig. 4 GC chromatography for residual aromatic compounds in SC1 (a), SC2 (b), SC3 (c), SC4 (d), SC5 (e), SC6 (f), SC7 (g) and SC8 (h) 
Fig. 5 Bacterial and fungal viable count ( $\mathrm{CFU} \mathrm{g} \mathrm{g}^{-1}$ of soil) during degradation of crude oil
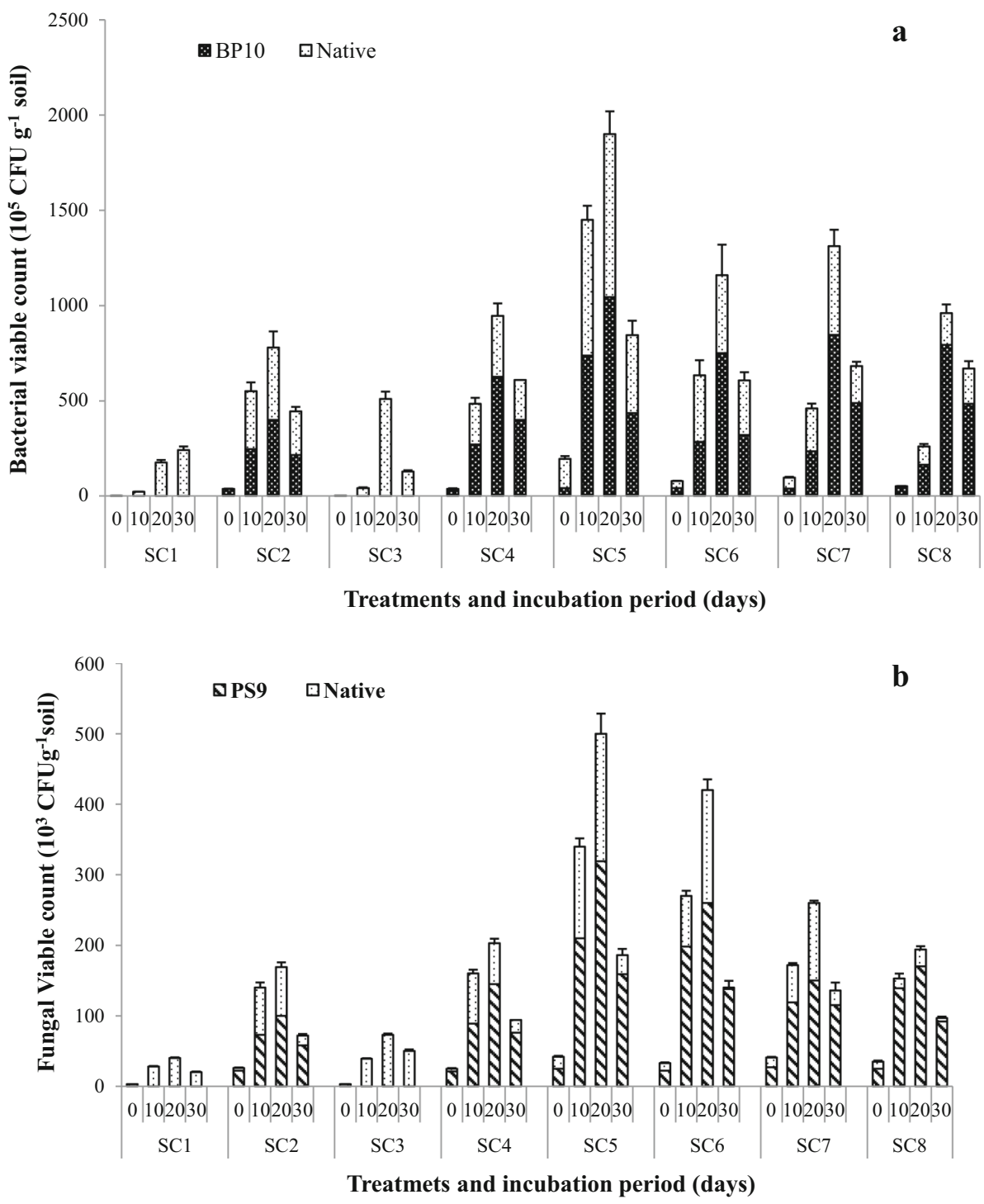

\section{Microbial growth in the presence of NPK and bulking agents}

The CFU of soil bacteria and fungi continued to increase gradually till $20 \mathrm{~d}$ of incubation and then started declining in most of the treatments (Fig. 5). Addition of NPK and bulking agents further boosted up the growth of both native and bioaugmented bacteria and fungi in different treatments. Among the treatment of bulking agents, CFU of native microbes as well as bioaugmented strains (BP10 and PS9) was found to be highest in the case of rice husk (SC5) treatment. $\mathrm{pH}$ of the rice husk (6.87) was more favorable for the growth of bacterial strain, i.e., BP10, while pH 5.37 of sugarcane bagasse preferably boosted the growth of fungal strain, i.e., PS9.

The in situ degradation of petroleum hydrocarbons is often limited due to lack of nutrients $(\mathrm{N}, \mathrm{P})$ and anoxia in the soil (Jørgensen et al. 2000). Earlier, it was suggested that a reduction in phosphorus level, due to phosphate fixation, was also a limiting factor for degradation of hydrocarbon (Vincent et al. 2011). However, application of excess fertilizer should be avoided, as it might lead to high $\mathrm{pH}$ and high concentration of chemicals like nitrogen which might be toxic to the soil microbes (Prince and McMillen 2002). Application of bulking agents could be an answer to such problems, and it might help in providing necessary nutrients required for stimulated growth of native microbes that were involved in remediation of crude oil-contaminated sites (Yakubu et al. 2009). They also help in immobilization of bacteria during crude oil degradation (Hazaimeh et al. 2014). Immobilized bacterial consortium on saw dust and oil palm empty fruit bunch enhanced TPH degradation by 15.85 and $17.52 \%$, respectively, and shortened the duration (from 8 to 6 weeks) of complete 
Fig. 6 Different enzyme activities [dehydrogenase (a), catalase (b) and laccase (c)] expressed during degradation of crude oil
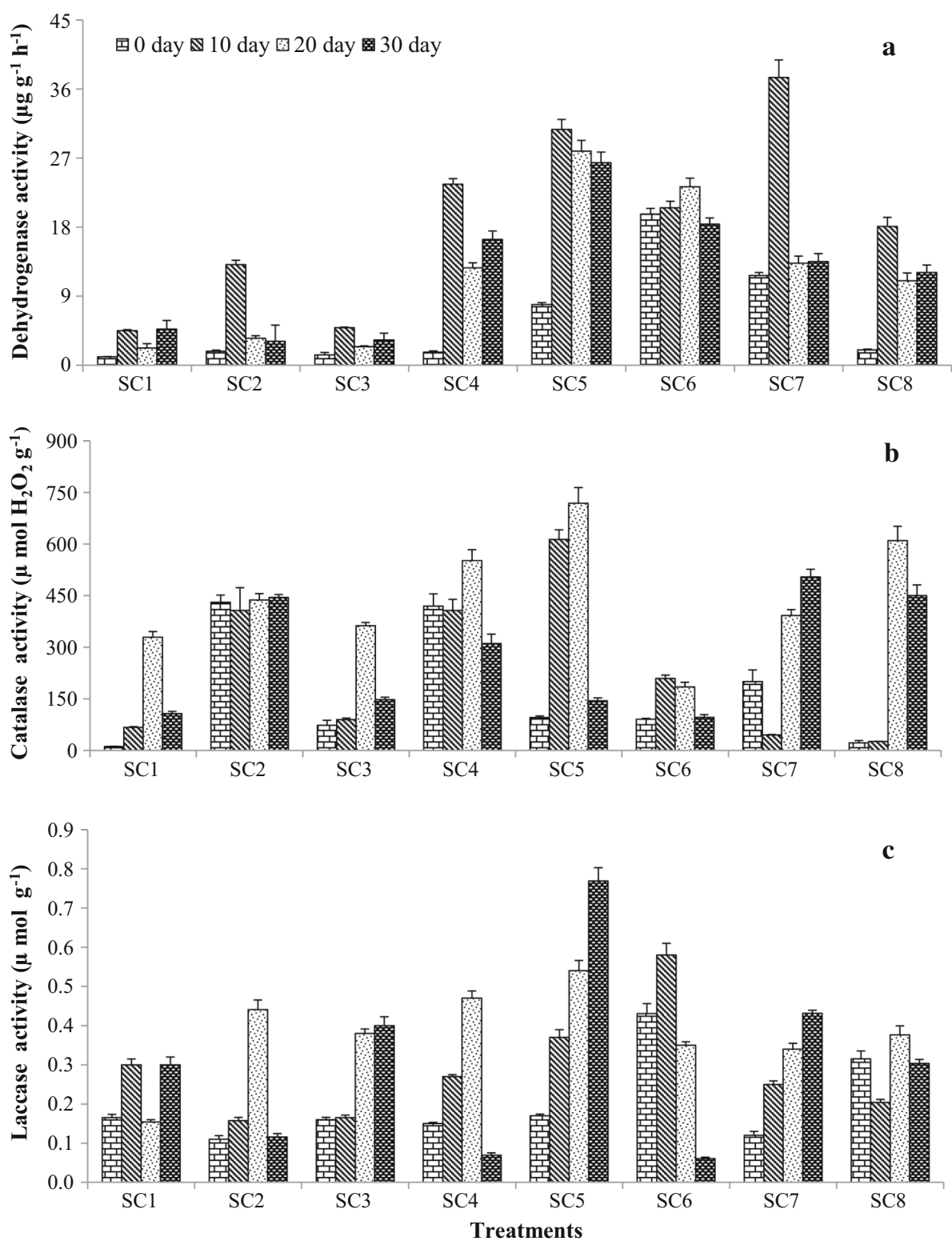

degradation by $25 \%$ compared to free bacterial consortium without bulking agents (Hazaimeh et al. 2014).

\section{Effect of NPK and bulking agents on enzyme induction}

Since the soil samples taken for bioaugmentation and biostimulation experiments were not sterilized, we preferred to see the overall impact of bioaugmentation and biostimulation on the induction of specific degradative enzymes as the natural soil might also contain some native microbial flora. The results showed that the degradation of total petroleum hydrocarbon was commensurating the expression of degradative enzymes in the contaminated soil (Figs. 6, 7). The soil dehydrogenase activity was found to be maximum after 10 days of incubation period in almost all the treatments (Fig. 6a). The highest dehydrogenase activity was observed in SC7 $\left(37.5 \mu \mathrm{g} \mathrm{g}^{-1} \mathrm{~h}^{-1}\right)$ on 10th day of treatment, followed by SC5 $\left(27.91 \mu \mathrm{g} \mathrm{g}^{-1} \mathrm{~h}^{-1}\right)$ on 20th day of treatment.

Among all the treatments, maximum catalase activity was recorded in SC5, i.e., 613 and $713 \mu \mathrm{mol}_{2} \mathrm{O}_{2} \mathrm{~g}^{-1}$, after 10 and 20 days of incubation, respectively, while the highest catalase activity was recorded in SC7 (504 $\mu$ mol $\mathrm{H}_{2} \mathrm{O}_{2} \quad \mathrm{~g}^{-1}$ ) after 30 days of incubation (Fig. 6b). According to Margesin et al. (2004), soil dehydrogenase, catalase and urease activities were induced immediately after oil contamination, attaining maximum values after 11-25 days, and then declined with decreasing hydrocarbon content. Yan et al. (2013) found a positive 
Fig. 7 Activity of catechol 1,2 dioxygenase (a) and catechol 2,3 dioxygenase (b) expressed during degradation of crude oil
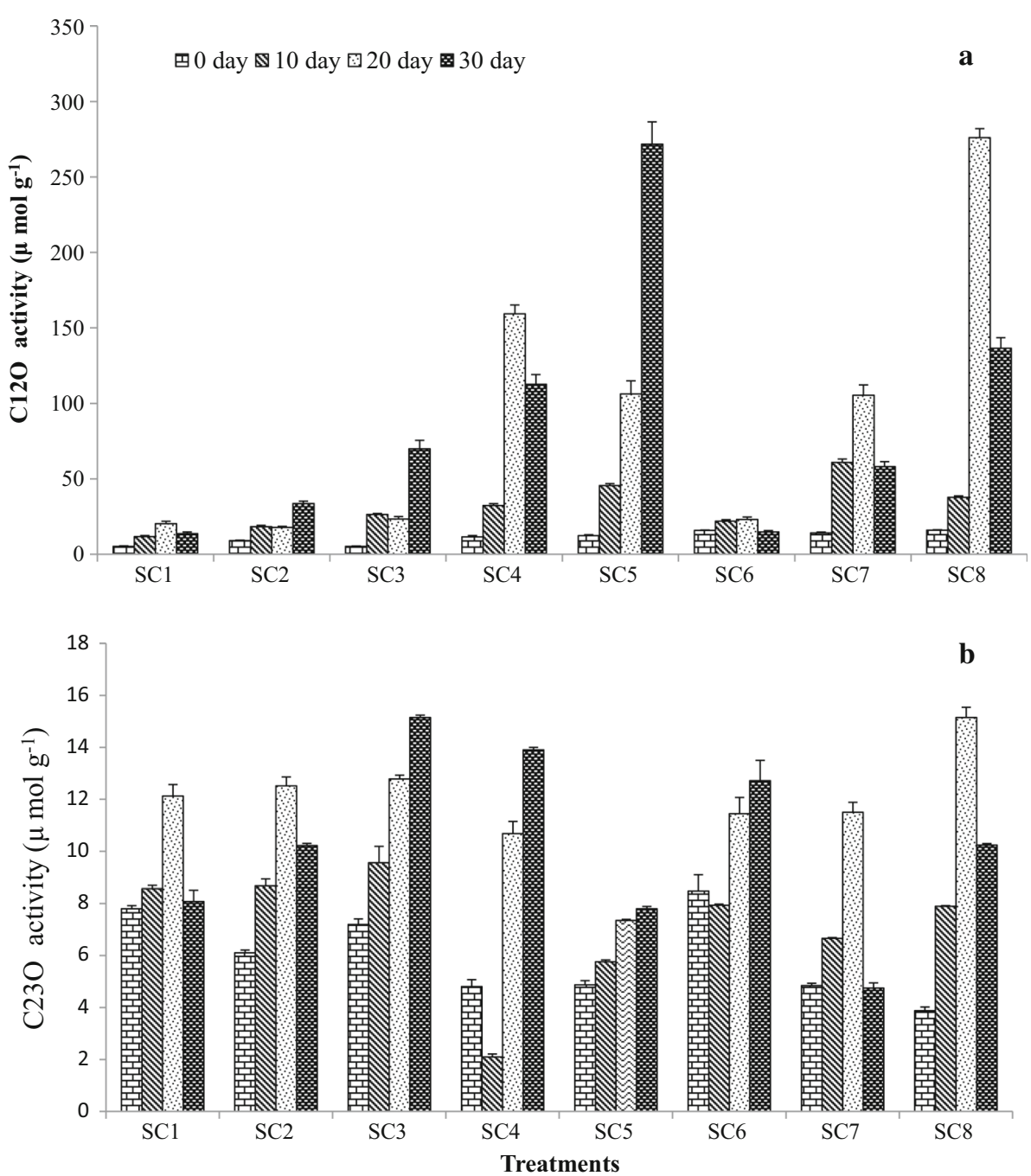

correlation between rate of crude oil degradation and dehydrogenase activity.

Laccase is copper-containing oxidase enzyme which catalyzes the ring cleavage. This enzyme is reported to be the most prevalent in fungi during petroleum hydrocarbon degradation. In the present investigation, the laccase activity was found to be the highest in SC5 $(0.77 \mu$ mol $\mathrm{g}^{-1}$ ) after 30 days of incubation, indicating that rice husk was more suitable bulking agents than other bulking materials (Fig. 6c).

In the present study, maximum activity of catechol 1, 2 dioxygenase (Fig. 7a) was $276.11 \mu \mathrm{mol} \mathrm{g}^{-1}$ in SC8, while maximum activity of catechol 2, 3 dioxygenase (Fig. 7b) was only $15.15 \mu \mathrm{mol} \mathrm{g}^{-1}$ in same treatment. Hence, catechol 1, 2 dioxygenase activities was found about 18-fold higher than catechol 2, 3 dioxygenase activities. Invariably, C120 activity was found to be higher in all treatments than $\mathrm{C} 23 \mathrm{O}$ activity which indicated that the degradation of aromatic fraction of crude oil was preferably favored by ortho-cleavage. However, catechol oxidation was enhanced during later period of incubation.

As the microorganisms play an important role in bioremediation of petroleum hydrocarbons, the soil enzyme activity and microbial count could be the common indices to describe the microbial activities during bioremediation of crude oil (Bahrampour and Moghanlo 2012). Various authors (Amenaghawon et al. 2014; Chromo et al. 2010; $\mathrm{Xu}$ and $\mathrm{Lu} 2010$ ) reported the positive effect of inorganic and organic fertilizers in the degradation of petroleum hydrocarbon in soil, but rarely anyone has reported the effect of bulking agents on the activity of microbial enzymes during degradation of crude oil. Among all the bulking agents used, rice husk was highly supportive to microbial biomass as well as induced activity of degradative enzymes in soil. Enzyme induction during the degradation of crude oil depends on the crude oil composition and their metabolic products. Therefore, Hollaway et al. (1980) supported the views that consortia with broad 
enzymatic capacities are more effective in the degradation of hydrocarbons in any environment (soil or water).

\section{pH}

$\mathrm{pH}$ of soil used in this study was found to be slightly basic in nature, but addition of NPK and bulking agents decreased the soil $\mathrm{pH}$ to different extents. A maximum decline in soil $\mathrm{pH}$ (6.12) was recorded in the presence of sugarcane bagasse in SC6, possibly due to more acidic nature of sugarcane bagasse, when compared to other bulking agents. With increasing incubation period, $\mathrm{pH}$ was changed according to the nature of metabolites formed during hydrocarbon degradation and finally, it was recorded in the range of 7.23-7.63 in all the treatments (data not shown).

The $\mathrm{pH}$ range for better growth of the majority bacteria lies between $\mathrm{pH} 6.5$ and 8.5, while $\mathrm{pH}$ condition required for the yeast and molds lies in the range of $\mathrm{pH} 4.5-5.5$. Thus, an optimal $\mathrm{pH}$ range for biodegradation of crude oil might be considered between $\mathrm{pH} 6.0$ and 8.5. In case of microbial degradation of crude oil in soil, the contribution made by bacterial strains has upper hand than fungi as evident from the results in Fig. 1. Results on viable count also depicted predominantly higher bacterial population than fungi (Fig. 5). Thus, providing an optimum $\mathrm{pH}$ condition between $\mathrm{pH}$ 6-8.5 is supportive to bacterial population, and therefore, it is supporting the biodegradation process. Satishkumar et al. (2008) found that $\mathrm{pH}$ ranging between 7 and 8 was more favorable for all the bacterial isolates and mixed bacterial consortium for degradation of crude oil. Similarly, Salmon et al. (1998) reported that $\mathrm{pH}$ 7 was the optimum $\mathrm{pH}$ for degradation of hydrocarbon. However, Rahman et al. (2002) reported that extreme $\mathrm{pH}$ on either side might cause negative effect on the ability of hydrocarbon-degrading microbial populations.

\section{Conclusion}

This study clearly demonstrated the application of bulking agents, i.e., vermicompost, sugarcane bagasse, rick husk and coconut coir, along with inorganic fertilizer (NPK) in biodegradation of TPH by microbial consortium (Pseudomonas stutzeri $\mathrm{BP} 10$ and Aspergillus niger PS9) not only as biostimulant, but also as inducers of degrader enzymes released by the microorganisms. The present study emphasizes on the application of compatible consortium under optimized conditions in petroleum hydrocarboncontaminated soils for degradation of petroleum hydrocarbon. Besides, application of required amount of biostimulants (NPK fertilizers and bulking agents, particularly the rice husk) can favorably accentuate both the biomass as well as biodegradation process.

Acknowledgments Authors are thankful to Director, CSIR-NBRI, UP (India), for providing the facilities to execute this study and CSIR HQ for financial support to the project NWP019. Authors also acknowledge Dr. Dilip Kumar, CSIR-NIEST, Jorhat, West Bengal (India), for providing us the bacterial strain $\mathrm{NJ} 2$ which was used in this investigation.

\section{References}

Agbor RB, Ekpo IA, Osuagwa AN, Udofia UV, Okpako EC, Antai SP (2012) Biostimulation of microbial degradation of crude oil polluted soil using cocoa pod husk and plantain peels. J Microbiol Biotechnol Res 2(3):464-469

Amenaghawon AN, Osunbor O, Obahiagbon KO (2014) Impact of nutrients, aeration and agitation on the bioremediation of crude oil polluted water using mixed microbial culture. Int J Sci Res Environ Sci 2(2):43-48

Bahrampour T, Moghanlo V (2012) Evaluation of soil biological activity after soil contaminating by crude oil. Int J Agri Res Rev 2(6):671-679

Beers JRF, Sizer IW (1952) A spectrophotometric method for measuring the breakdown of hydrogen peroxide by catalase. J Biol Chem 195:133-140

Beškoski VP, Gojgić-Cvijović GĐ, Milić JS, Ilić MV, Miletić Srđan B, Jovančićević BS, Vrvić-Miroslav M (2012) Bioremediation of soil polluted with crude oil and its derivatives: microorganisms, degradation pathways, technologies. Hemijska Ind 66(2):275-289

Binazadeh M, Karimi IA, Li Z (2009) Fast biodegradation of long chain n-alkanes and crude oil at high concentrations with Rhodococcus sp. Moj-3449. Enzyme Microbiol Technol 45(3): 195-202

Boopathy R (2000) Factors limiting bioremediation technologies. Bioresour Technol 74:63-67

Chromo M, Sharifi HS, Motamedi H (2010) Bioremediation of a crude oil-polluted soil by applying of fertilizers. Iran J Environ Health Sci Eng 7(4):319-326

Das TT, Gohel HR, Panchal MR, Ghosh SK, Braganza VJ (2014) Determination of crude oil degradation efficiency of glass biofilm of isolated bacterium and fungus. Int Res J Biol Sci 3(2):67-69

Gilman JC (1990) A manual of soil fungi. Daya Publishing House, New Delhi

Hamzah A, Salleh SN, Md Lee SL, Sarmani S (2012) Bioaugmentation of microbial consortia and supplementation of bulking agents in removal of crude oil from soil. In: Mendez-Vila A (ed) Microbes in applied research-current advances and challenges. Malaga, Spain, pp 39-43

Hazaimeh M, Mutalib SA, Abdullah PS, Kee WK, Surif S (2014) Enhanced crude oil hydrocarbon degradation by self-immobilized bacterial consortium culture on sawdust and oil palm empty fruit bunch. Ann Microbiol. doi:10.1007/s13213-014-0821-3

Hegeman GD (1966) Synthesis of the enzymes of the mandelate pathway by Pseudomonas putida. I. Synthesis of the enzymes in the wild type. J Bacteriol 91:1140-1154

Hollaway SL, Faw GM, Sizemore RK (1980) The bacterial community composition of an active oil field in the Northwestern Gulf of Mexico. Mar Pollut Bull 11(6):153-156

Huesemann MH, Hausmann TS, Fortman TJ (2003) Assessment of bioavailability limitations during slurry biodegradation of 
petroleum hydrocarbons in aged soil. Ecol Toxicol Chem 22(12):2853-2860

IEO (2014) International Energy Outlook DOE/EIA-0484. http:// www.eia.gov/forecasts/ieo/pdf/0484\%282014\%29.pdf

Jin S, Fallgren PH (2007) Site-specific limitations of using urea as nitrogen source in biodegradation of petroleum wastes. Soil Sediment Contaminat 16(5):497-505

Jørgensen KS, Puustinen J, Suortti AM (2000) Bioremediation of petroleum hydrocarbon-contaminated soil by composting in biopiles. Environ Pollut 107:245-254

Kadali KK, Simons KL, Sheppard PJ, Ball AS (2012) Mineralization of weathered crude oil by a hydrocarbonplastic consortia in marine microcosms. Water Air Soil Pollut 223:4283-4295

Khashayar T, Mahsa T (2010) Biodegradation potential of petroleum hydrocarbons by bacterial diversity in soil. World Appl Sci J 8(6):750-755

Klecka GM, Gibson DT (1981) Inhibition of catechol 2, 3-dioxygenase from Pseudomonas putida by 3-chlorocatechol. Appl Environ Microbiol 41(5):1159-1165

Kumari B, Singh SN, Singh DP (2012) Characterization of two biosurfactant producing strains in crude oil degradation. Process Biochem 47(12):2463-2471

Kumari B, Singh SN, Farah D, Sharma M, Pandey V, Singh DP (2013) Elucidation of pyrene degradation pathway in bacteria. Adv Bioresour 4(2):151-160

Lavania M, Cheema S, Sarma PM, Mandal AK, Lal B (2012) Biodegradation of asphalt by Garciaella petrolearia TERIG02 for viscosity reduction of heavy oil. Biodegrad 23:15-24

Li L, Cunningham CJ, Pas V, Philp JC, Barry DA, Anderson P (2004) Field trial of a new aeration system for enhancing biodegradation in a biopile. Waste Manag 24:127-137

Liu PWG, Wang SY, Huang SG, Wang MZ (2012) Effects of soil organic matter and ageing on remediation of diesel contaminated soil. Environ Technol 33(23):2661-2672

Margesin R, Zimmerbauer A, Schinner F (2004) Monitoring of bioremediation by soil biological activities. Chemosphere 40:339-346

Mishra S, Jyot J, Kuhad RC, Lal B (2001) In situ bioremediation potential of an oily sludge-degrading bacterial consortium. Curr Microbiol 43:328-335

Mortazavi B, Horel A, Beazley MJ, Sobecky PA (2013) Intrinsic rates of petroleum hydrocarbon biodegradation in gulf of Mexico inter tidy sandy sediments and its enhancement by organic substrates. J Hazard Mater 244-45:537-544
Prince R, McMillen S (2002) Summary of PERF bioremediation projects. In: Presentation at DOE/PERF bioremediation workshop. May 30 Houston

Rahman KSM, Thahira-Rahman J, Lakshmanperumalsamy P, Banat IM (2002) Towards efficient crude oil degradation by a mixed bacterial consortium. Bioresour Technol 85:257-261

Rizi MS, Sepahi AA, Tabatabaee MS (2012) Crude oil biodegrdation by a soil indigenous Bacillus sp. isolated from Lavan Island. Biorem J 16(4):218-224

Salmon C, Crabos JL, Sambuco JP, Bessiere JM, Basseres A, Caumette P, Baccou JC (1998) Artificial wetland performances in the purification efficiency of hydrocarbon wastewater. Water Air Soil Pollut 104:313-329

Sampath R, Venkatakrishnan H, Ravichandran V, Chaudhury RR (2012) Biochemistry of TBT degrading marine Pseudomonas isolated from Indian coastal water. Water Air Soil Pollut 223:99-106

Satishkumar M, Binupriya AR, Balk SH, Yun SE (2008) Biodegradation of crude oil by individual bacterial strains and mixed bacterial consortium isolated from hydrocarbon contaminated areas. Clean 36(1):92-96

Shahaby AF (2014) Assessment mixed culture of Actinomyces and Sacchromyces for biodegradation of complex mineral oil hydrocarbon. Int J Curr Microbiol App Sci 3(4):401-414

Stevenson IL (1956) Some observations on the microbial activity in remoistened air-dried soils. Plant Soil 8(2):170-182

Trémier A, Telia C (2009) Barrington S. Effect of initial physical characteristics on sludge compost performance. Bioresour Technol 100:3751-3758

Vincent AO, Felix E, Weltime MO, Ize-iyamu OK, Daniel EE (2011) Microbial degradation and its kinetics on crude oil polluted soil. Res J Chem Sci 1(6):8-14

Wu M, Chen L, Tian Y, Ding Y, Dick WA (2013) Degradation of polycyclic aromatic hydrocarbons by microbial consortia enriched from three soils using two different culture media. Environ Pollut 178:152-158

Xu YH, Lu M (2010) Bioremediation of crude oil-contaminated soil: comparison of different biostimulation and bioaugmentation treatments. J Hazard Mater 183(1-3):395-401

Yakubu BM, Ma H, Zhang CY (2009) Biodegradation of crude oil in soil using chicken manure. Int J Environ Pollut 36:400-410

Yan S, Wan Q, Qu L, Li C (2013) Characterization of oil- degrading bacteria from oil-contaminated soil and activity of their enzymes. Biotechnol Biotechnol EQ.27/2013/4, 3932-3938 